\section{Embryonic and foetal Islet-1 positive cells in human hearts are also positive to c-Kit}

\author{
C. Serradifalco, ${ }^{1}$ P. Catanese, ${ }^{1}$ L. Rizzuto, ${ }^{1}$ \\ F. Cappello, ${ }^{1}$ R. Puleio, ${ }^{3}$ V. Barresi, ${ }^{2}$ \\ C.M. Nunnari, ${ }^{2}$ G. Zummo, ${ }^{1}$ V. Di Felice ${ }^{1}$ \\ ${ }^{1}$ BioNeC Department, University of \\ Palermo, Italy; '2Department of Human \\ Pathology, University of Messina, Italy; \\ ${ }^{3}$ Istituto Zooprofilattico Sperimentale \\ della Sicilia, Palermo, Italy
}

\section{Abstract}

During embryogenesis, the mammalian heart develops from a primitive heart tube originating from two bilateral primary heart fields located in the lateral plate mesoderm. Cells belongings to the pre-cardiac mesoderm will differentiate into early cardiac progenitors, which express early transcription factors which are also common to the Isl-1 positive cardiac progenitor cells isolated from the developing pharyngeal mesoderm and the foetal and post-natal mice hearts. A second population of cardiac progenitor cells positive to c-Kit has been abundantly isolated from adult hearts. Until now, these two populations have been considered two different sets of progenitor cells present in the heart in different stages of an individual life. In the present study we collected embryonic, foetal and infant hearts, and we tested the hypotheses that c-Kit positive cells, usually isolated from the adult heart, are also present in the intra-uterine life and persist in the adult heart after birth, and that foetal Isl-1 positive cells are also positive to c-Kit. Using immunohistochemistry we studied the temporal distribution of Isl-1 positive and c-Kit/CD105 double positive cells, and by immunofluorescence and confocal analysis we studied the co-localization of c-Kit and Isl-1 positive cells. The results indicated that cardiomyocytes and interstitial cells were positive for c-Kit from the $9 \mathrm{t}^{\mathrm{h}}$ to the $19^{\mathrm{h}}$ gestational week, that cells positive for both c-Kit and CD105 appeared in the interstitium at the $17^{\mathrm{h}}$ gestational week and persisted in the postnatal age, and that the Isl-1 positive cells were a subset of the c-Kit positive population.

\section{Introduction}

The mechanisms involved in establishing the early heart and regulating its morphogenesis have been widely studied. ${ }^{1}$ During embryo- genesis, the atrioventricular (A-V) canal and the sinu-atrial segment at the venous pole as well as the conotruncus at the arterial pole are added to the heart tube during tube looping. ${ }^{2,3}$ Most of the cells that will differentiate into the developing myocardium are derived from a population of progenitor cells located in the pharyngeal mesoderm, termed the secondary heart field (SHF)..$^{4-6}$

Cells belongings to the pre-cardiac mesoderm will differentiate into early cardiac progenitors which can in turn differentiate into primitive cardiomyocytes, smooth muscle cells and endothelial cells. ${ }^{7}$ Known markers of precardiac cells of the primary and the secondary heart field are Nkx2.5 and GATA-4. ${ }^{4}$ The expression of these two transcription factors is common to the LIM homeobox transcription factor positive (Isl-1+ $1^{+}$cardiac progenitor cells (CPCs) and the developing pharyngeal mesoderm $^{8}$ as well as foetal and post-natal mice hearts. ${ }^{9}$ This small number of Isl-1+ cells has been identified as a residue of the migrating SHF cells and may be considered resident progenitor cells in the myocardium in the postnatal age. ${ }^{10}$

With regard to the Isl- $1^{+}$cell distribution, Genead et al. ${ }^{11}$ described the frequency of Isl$1^{+}$cells in the early first trimester human embryonic heart. They did not observe differences among the outflow tract, atria and right ventricle, confirming what had been previously reported for the late first and early second trimester. ${ }^{12}$ Clusters of Isl- $\mathbf{1}^{+}$cells were identified in the right atrial wall of foetal and new born hearts, whereas occasional Isl- $1^{+}$cells have been found in the ventricular regions. ${ }^{13}$ Isl-1 has been identified as a marker of CPCs in the adult rat heart, ${ }^{14,15}$ giving support to the hypothesis that some cells from the embryo may also persist into adulthood. ${ }^{16}$

Most studies concerning the localisation of CPCs in the developing heart have been performed in mice or chicks. The localisation and identification of CPCs in the human foetal and adult heart has been investigated for the first time by Limana and colleagues, ${ }^{17}$ with their analysis limited to epicardium and CD $34^{+}$or c$\mathrm{Kit}^{+}$cells. Cells expressing c-Kit were identified also in the human foetal and post-natal myocardium specimens. These cells were located within the connective tissue and within muscle bundles. Their number declined over time until the first post-natal month. ${ }^{18}$

The transmembrane receptor tyrosine kinase c-Kit is expressed on the cell surface of stem cells during haematopoiesis, ${ }^{19}$ dental pulp stem cells originating from the neural crest cells,${ }^{20}$ in the developing pancreas ${ }^{21}$ and recently as been proposed as a useful marker to differentiate primary melanoma from compound nevi. ${ }^{22}$ Apart from the many studies on the expression and localization of this receptor, c-Kit has been pro-
Correspondence: Dr. Valentina Di Felice, Human Anatomy Section, BioNeC Department, via Del Vespro 129, 90127 Palermo, Italy.

$\mathrm{Tel} / \mathrm{Fax}+39.091 .6553575$.

E-mail: vdfelice@inwind.it

Key words: Isl-1, c-Kit, human heart, embryo, foetus.

Acknowledgements: this research was supported by MIUR ex-60\% Dott. Valentina Di Felice (Ministero dell'Università e della Ricerca) 2007 and "Ministero della Salute" Ricerca Finalizzata 2007 Prof. Giovanni Zummo.

Contributions: CS, immunohistochemistry and data analysis; PC, immunohistochemistry; FC, consultant for anatomical pathology; VB, CMN, sample collection; GZ, data analysis and manuscript writing; VDF, PI and manuscript writing; $\mathrm{RP}$, confocal analysis.

Conflict of interest: the authors report no conflicts of interest.

Received for publication: 1 August 2011.

Accepted for publication: 13 October 2011.

This work is licensed under a Creative Commons Attribution NonCommercial 3.0 License (CC BYNC 3.0).

CC Copyright C. Serradifalco et al., 2011

Licensee PAGEPress, Italy

European Journal of Histochemistry 2011; 55:e41 doi:10.4081/ejh.2011.e41

posed also as the most important marker for adult CPCs. ${ }^{23,24}$ The first isolation and characterisation of adult human CPCs has been performed from percutaneous right ventricular endocardial biopsy specimens by Smith and colleagues. ${ }^{25}$ Multipotent CPCs from human cardiospheres consistently expressed c-Kit and CD105, the regulatory component of the transforming growth factor- $\beta$ receptor complex that is important in angiogenesis ${ }^{26}$ and haematopoiesis. ${ }^{27}$ Therefore, it seems that c-Kit ${ }^{+}$cells are CPCs homing the myocardium in the adulthood, while Isl- $1^{+}$cells have been proposed as a different subset of undifferentiated cells able to generate endothelial cells, cardiomyocytes, smooth muscle cells and cardiac fibroblasts but present only in the developing heart and persisting in the post-natal age. ${ }^{8,28,29}$ In the mean time another subset of cardiac undifferentiated cells (epicardial progenitors) has been identified which barely participate in atria, right ventricle and outflow tract formation and that are detectable in the murine and human foetal, but not adult hearts. ${ }^{30}$ In the present study, we analysed human hearts from embryos, foetuses and neonates at different gestational ages to determine the presence and co-localization of the Isl$1^{+}$CPCs identified in the embryonic and postnatal heart, and the $\mathrm{c}-\mathrm{Kit}^{+} / \mathrm{CD} 105^{+}$cells described in the adult heart, to understand if the 
c-Kit ${ }^{+}$cells abundantly isolated from adult hearts are present also in the embryonic and foetal heart and if they are a different subset of the extensively studied Isl- $1^{+}$cells.

\section{Materials and Methods}

\section{Human cardiac samples}

Cardiac tissue samples, comprising the endocardial, myocardial, and epicardial layers of the ventricles, were obtained by autopsy from embryos, foetuses, preterm infants, and term infants and collected, after written consent from the mother, in the Department of Human Pathology of the University of Messina, Italy. The procedures followed were in accordance with the ethical standards of the responsible committee on human experimentation and with the Helsinki Declaration of 1975. The Ethics Committee of the University of Messina approved the study.

Gestational age of the foetuses ranged between 9 and 40 weeks, as shown in Table 1 and Table 2. Specifically, our cohort comprised 25 samples. The causes related to the death of the analysed foetuses and of the preterm and term infants are shown in Table 1 and Table 2. Autopsies and sample collections were carried out immediately after delivery with less than a 24-hour interval since foetal death had occurred.

All samples were fixed in 10\% formalin and embedded in paraffin for morphological diagnostic evaluation (haematoxylin/eosin) and immunohistochemistry.

Table 1. Clinical and morphological data and c-Kit/CD105 expression in 1 embryo, 12 foetuses, 1 preterm infant and 1 term infant.

\begin{tabular}{|c|c|c|c|c|c|c|c|c|}
\hline Case No. & Trimester & $\begin{array}{l}\text { Gestational } \\
\text { age (wks) }\end{array}$ & $\begin{array}{l}\text { Age at } \\
\text { death }\end{array}$ & $\begin{array}{c}\text { Cause of } \\
\text { death }\end{array}$ & $\begin{array}{c}\text { Heart } \\
\text { malformations }\end{array}$ & Cardiomyocytes & Endocardium & $\begin{array}{l}\text { Intestitial } \\
\text { cells }\end{array}$ \\
\hline \multicolumn{9}{|l|}{ Embryo } \\
\hline 1 & I & 9 & 9 wks & $\begin{array}{r}E \\
\text { def }\end{array}$ & $\begin{array}{l}\text { Endocardial cushion } \\
\text { ect (AVC of the heart) }\end{array}$ & & CD105+ & c-Kit+/CD105 \\
\hline \multicolumn{9}{|l|}{ Foetuses } \\
\hline 2 & I & 13 & 13 wks & SA for chorioamnionitis & Absent & c-Kit+ & CD105+ & c-Kit+/CD105- \\
\hline 3 & II & 14 & 14 wks & TA for CRS & VSD & c-Kit + & CD105+ & c-Kit+/CD105- \\
\hline 4 & II & 14 & 14 wks & SA for chorioamnionitis & Absent & c-Kit+ & CD105+ & c-Kit+/CD105- \\
\hline 5 & II & 14 & 14 wks & TA for cerebral malformations & Absent & c-Kit+ & CD105+ & c-Kit+/CD105- \\
\hline 6 & II & 15 & 15 wks & SA for chorioamnionitis & Absent & c-Kit+ & CD105+ & c-Kit+/CD105- \\
\hline 7 & II & 16 & 16 wks & SA for abruption placentae & Absent & c-Kit+ & CD105+ & $\mathrm{c-Kit+/CD105-}$ \\
\hline 8 & II & 17 & 17 wks & TA for cerebral malformations & Absent & c-Kit+/- & CD105+ & $\mathrm{c}-\mathrm{Kit}+/ \mathrm{CD} 105+$ \\
\hline 9 & II & 18 & 18 wks & TA for MCA & Absent & c-Kit+/- & CD105+ & c-Kit+/CD105+ \\
\hline 10 & II & 19 & 19 wks & TA for PKD, UBH, CLGP left, PEV bilateral & Absent & $\mathrm{c}-\mathrm{Ki}+/-$ & CD105+ & c-Kit +/CD105+ \\
\hline 11 & II & 22 & 22 wks & SA for chorioamnionitis & Absent & c-Kit+/- & CD105+ & c-Kit +/CD105+ \\
\hline 12 & II & 22 & 22 wks & SA for chorioamnionitis & Absent & c-Kit - & CD105+ & c-Kit +/CD105+ \\
\hline 13 & III & 27 & 27 wks & SA for abruption placentae & Absent & c-Kit - & CD105+ & c-Kit +/CD105+ \\
\hline $\begin{array}{l}\text { Preterm infant } \\
14\end{array}$ & III & 36 & 1 day & Respiratory failure & Absent & c-Kit - & CD105+ & c-Kit +/CD105+ \\
\hline $\begin{array}{l}\text { Term infant } \\
15\end{array}$ & III & 40 & 6 yrs & Disseminate intravascular coagulation & Absent & c-Kit - & CD105+ & c-Kit +/CD105+ \\
\hline
\end{tabular}

TA, therapeutic abortion; SA, spontaneous abortion; CLGP, cheilo-gnatho-palatischisis; CRS, caudal regression syndrome; MCA, multiple congenital anomalies; PEV, pes equino varus; PDK, polycystic kidney disease.

Table 2. Clinical and morphological data and number of Isl-1 positive cells per area $\left(\mathrm{mm}^{2}\right)$ in 7 foetuses, 2 preterm infants and 1 term Infant.

$\begin{array}{ccccc}\text { Case No. Trimester Gestational Age at } & \text { Cause of } & \text { Growth } & \text { Heart } & \text { Section area } \\ \text { age (wks) death } & \text { death } & \text { defects } & \text { malformations } & \left(\mathrm{mm}^{2}\right)\end{array}$

\section{Foetuses}

\begin{tabular}{|c|c|c|c|c|c|}
\hline 16 & II & 14 & 14 wks & Abruptio placentae & Absent \\
\hline 17 & II & 15 & 15 wks & $\begin{array}{l}\text { TA for Prune-Belly } \\
\text { syndrome }\end{array}$ & Absent \\
\hline 18 & II & 16 & 16 wks & TA for trisomy 21 & IUGR \\
\hline 19 & II & 19 & 19 wks & TA for trisomy 21 & Absent \\
\hline 20 & II & 20 & 20 wks & TA for trisomy 21 & Absent \\
\hline 21 & II & 21 & $21 \mathrm{wks}$ & TA for trisomy 21 & Absent \\
\hline 22 & II & 22 & 22 wks & TA for cerebral & Absent \\
\hline
\end{tabular}

$\begin{array}{ccc}\text { Absent } & 56171.5 \pm 11561.46 & 4.523 \pm 1.22 \\ \text { Absent } & 46063 \pm 3055.72 & 3.543 \pm 0.15 \\ & & \\ \text { Absent } & 83666.33 \pm 2011.76 & 1.394 \pm 0.17 \\ \text { Absent } & 71642.66 \pm 4190.29 & 1.141 \pm 0.62 \\ \text { Absent } & 186604.66 \pm 9018 & 0.735 \pm 0.10 \\ \text { Absent } & 119550.33 \pm 4100.16 & 0.889 \pm 0.14 \\ \text { Absent } & 162438 \pm 7750.21 & 0.738 \pm 0.02\end{array}$

\begin{tabular}{|c|c|c|c|c|c|c|c|c|}
\hline \multicolumn{9}{|c|}{ Preterm infants } \\
\hline 23 & III & 26 & 8 days & Respiratory failure & IUGR & $\begin{array}{c}\text { Ventricular septal } \\
\text { hypertrophy }\end{array}$ & $101629 \pm 1409.49$ & $1.279 \pm 0.08$ \\
\hline 24 & III & 36 & $2 \mathrm{hrs}$ & Sepsis & Absent & $\begin{array}{l}\text { Ventricular septal } \\
\text { hypertrophy }\end{array}$ & $165575.33 \pm 2524.22$ & $0.664 \pm 0.05$ \\
\hline
\end{tabular}

Term infants

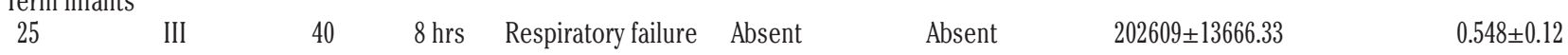

*Data for which a t-test for dependent samples was performed, $\mathrm{P}<0.05$. Gestational weeks (independent variable); Isl-1+ cells/mm² (dependent variable); TA, therapeutic abortion; IUGR, intrauterin growth retardation; UBH, urinary bladder hypoplasia; VSD, ventricular septal defect; VT, voluntary termination; +, strongly positive; +/-, weakly positive. 


\section{Immunohistochemistry}

Single immunohistochemistry was performed by a streptavidin-biotin complex method using LSAB2 kit (DAKO Co., Carpinteria, CA, USA). After deparaffination and rehydration, the tissue sections were incubated with the protein blocking agent (DAKO) for $10 \mathrm{~min}$ and the primary antibody for $1 \mathrm{~h}$. We used the anti-Isl-1 antibody (1:200, rabbit polyclonal, AB5754, Chemicon Int., Millipore Corp., Billerica, MA, USA). The linked primary antibody was detected with DAKO LSAB2 streptavidin-peroxidase system according to manufacturer's instructions. 3-Amino-9-ethylcarbazole (AEC) was used as a chromogen, whereas hematoxylin was used as a light counterstain.

Double immunohistochemistry was performed by a streptavidin-biotin complex for the goat polyclonal antibody (CD105) and labelled using polymer-alkalyne phosphatase (AP) for the rabbit polyclonal antibody (c-Kit). After deparaffination and rehydration the tissue sections were incubated with the Peroxidase Block solution (Vector Laboratories Inc., Burlingame, CA, USA) for $5 \mathrm{~min}$, washed in PBS for 5 min, and incubated with the antiCD105 goat polyclonal antibody (1:50, SC19793, Santa Cruz Biotechnology Inc., Santa Cruz, CA) for 30 min. After washing in PBS, sections were incubated with the biotinylated anti-goat secondary antibody (1:200, SC-2774, Santa Cruz Biotechnology Inc.) for $30 \mathrm{~min}$, and washed again in PBS. For the antibody detection the streptavidin-HRP complex (LSAB2 kit DAK0) was used for $10 \mathrm{~min}$. Sections were then rinsed in PBS with $0.1 \%$ Tween 20 (TPBS) for $5 \mathrm{~min}$, and incubated with 3,3'Diaminobenzidine (DAB-Vector Laboratories) as the HRP-substrate.

After the detection of the first antigen, sections were incubated with the Doublestain Block solution (Vector Laboratories) for $3 \mathrm{~min}$, washed in T-PBS for $5 \mathrm{~min}$, and incubated with the anti-c-Kit rabbit polyclonal antibody (1:200, KAP-TK005, Stressgen Bioreagents, Ann Arbor, MI, USA) for $30 \mathrm{~min}$. After washing with T-PBS for $5 \mathrm{~min}$, sections were incubated with a labelled polymer - AP secondary antibody (Vector Laboratories) for $30 \mathrm{~min}$, and washed again. Fast red (Vector Laboratories) was used as the AP substrate for 5 min. Sections were then washed in tap water and counterstained with hematoxylin for $1 \mathrm{~min}$. DAKO Aqueous mounting medium was used. Each tissue section was analysed by two independent observers (CS and PC) who evaluated the number of positive cells in three paraffin embedded sections independently stained.

To analyse the number of Isl-1 positive cells the area of each section was determined. It was taken a $100 \%-600$ dpi picture of each stained slide using an Epson Perfection 1200
Scanner connected to a personal computer. The section sizes were too big to be measured with pictures taken at the microscope. Each picture was then converted to an 8-bit picture, Brightness was adjusted and Threshold applied. On the Threshold pictures the Analyze particles function of the ImageJ Software (released by the NIH, http://rsbweb.nih.gov/ij) was applied to measure the area of the coloured sections. Data are shown in Table 2. An example of the area measurement is shown in Appendix Figure 1.

\section{Immunofluorescence}

After deparaffination and rehydration, tis- sue sections were blocked with 5\% BSA in PBS for $30 \mathrm{~min}$ and incubated with the first primary antibody overnight, one night for each antibody (1:50, anti-c-Kit, KAP-TK005, Stressgen Bioreagents; 1:50, anti-Isl-1, goat polyclonal, SC-23590, Santa Cruz Biotechnology Inc.). After washing with PBS, cells were further incubated with fluorescent secondary antibodies $1 \mathrm{~h}$ at room temperature (1:50, TRITC-conjugated anti-rabbit secondary antibody, T5268, Sigma-Aldrich, St. Louis, M0; 1:50 FITC-conjugated donkey anti-goat secondary antibody, SC-2024, Santa Cruz Biotechnology Inc.). In single immunofluorescence experiments nuclei were stained $10 \mathrm{~min}$ with $10 \mu \mathrm{g} / \mathrm{mL}$
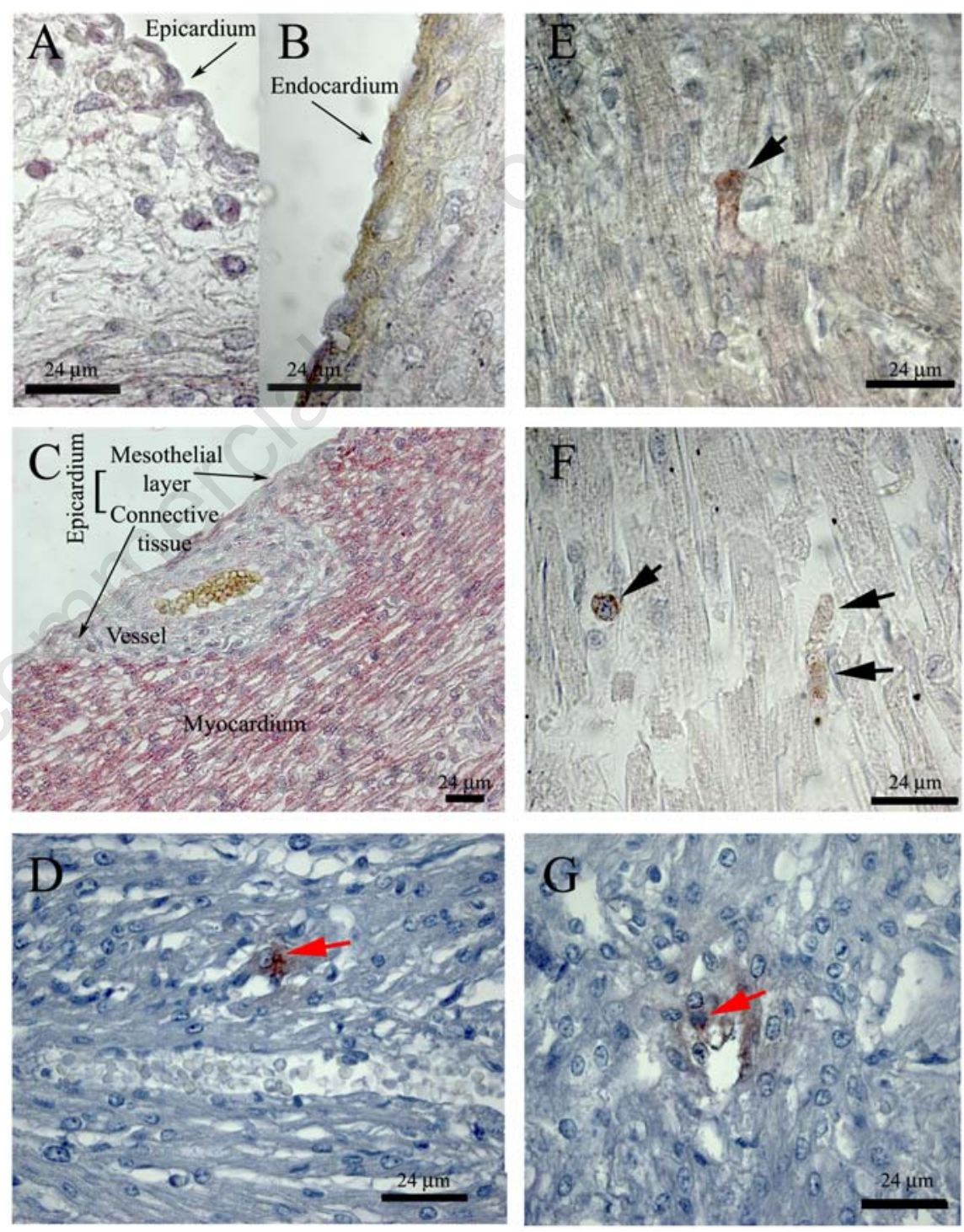

Figure 1. Identification of interstitial c-Kit+/CD105+ and Isl-1+ cells in human foetal and infant hearts before (A-D) and after (E-G) the 17th gestational week. A, B, C) c-Kit (Fast Red) and CD105 (DAB) double immunostaining in a 16-week foetal heart. E, F) c-Kit (Fast Red) and CD105 (DAB) double immunostaining in a preterm infant (36 weeks of gestation, $\mathrm{E})$ and in a term infant (6-year-old child. F) Black arrows indicate double stained cells. D) Isl-1 (AEC) single immunostaining in a 14-week foetal heart; red arrows indicate Isl-1 positive cells. G) Isl-1 (AEC) single immunostaining in a 21-week foetal heart. Double positive cells appeared deep red; red arrow indicate Isl-1 positive cells. 
Hoechst33342 staining in PBS (Invitrogen Corp., Carlsbad, CA, USA). In confocal experiments nuclei were stained 15 min with $1 \mu \mathrm{M}$ Toto-3 staining in PBS (T3604, Invitrogen Corp.). To avoid cross-reactions, sections were incubated with goat-anti-Isl-1 first and with rabbit anti-c-Kit after, and with donkey antigoat first and goat anti-rabbit after, in four different incubations.

To avoid autofluorescence of paraffin/formalin embedded sections, the samples were incubated in $0.1 \%$ Sudan Black in $70 \%$ ethanol for 5 min after nuclei staining. ${ }^{31}$ For imaging they were both used a Zeiss LSM5 Exciter Laser Scanning Confocal Microscope and a Leica CTR5000 fluorescent microscope. During confocal microscope observations all parameters for picture acquisition were kept the same and automatically saved.

\section{Statistical analysis}

Data are shown as mean values and the standard deviation has been calculated. The hypothesis that the number of Isl-1+ cells per $\mathrm{mm}^{2}$ varied with the gestational age was tested using a t-test of dependent samples $(\mathrm{P}<0.05)$. The hypothesis that there was a linear correlation between the gestational age of the foetuses and the number of Isl-1+ ${ }^{+}$cells per $\mathrm{mm}^{2}$ was tested using the Pearson coefficient $(\mathrm{P}<0.05)$. For the statistical analysis it was used the STATISTICA 6.0 software (StatSoft Italia srl, Vigonza, Italy).

\section{Results}

\section{Expression of c-Kit on the mem- brane of cardiomyocytes of foetal hearts}

To study the localization of c-Kit ${ }^{+} \mathrm{CPCs}$ previously isolated and characterized in the rat adult heart by our research group,$^{14}$ we performed immunohistochemistry and immunofluorescence experiments on heart samples from embryonic and foetal human hearts.

As shown in Table 1 and Figure 1 A-C, many interstitial and subepicardial cells and all cardiomyocytes were positive for c-Kit from the $9^{\text {th }}$ to the $17^{\text {th }}$ week of gestation, and sometimes also to the $22^{\text {nd }}$ week.

The expression of c-Kit on the surface of cardiomyocytes of the first and second gestational trimesters was confirmed by immunofluorescence experiments (Figure $2 \mathrm{~A}, \mathrm{~F}$ ). In the only embryonic sample $\left(9^{\text {th }}\right.$ gestational week) some structures similar to the primordial myocardium of the cardiac tube were clearly positive to c-Kit (Figure 2 B-C). Later on during gestation, clusters of $\mathrm{c}^{-\mathrm{Kit}^{+}}$cells were present (Figure 2 D).

\section{Immunolocalisation of cardiac pro- genitor cells}

In literature there have been clearly identified two main populations of cardiac progenitor cells: human cells double positive for c-Kit and CD105 in adult hearts by Smith et al. ${ }^{25}$ and cells positive for Isl-1 by Laugwitz et al. ${ }^{9}$ in the developing heart. To localize separately the two populations in the human foetal hearts we performed a double immunostaining for c-Kit and CD105, and a single immunostaining for Isl-1. Results were summarised in Table 1 for cKit/CD105 and Table 2 for Isl- 1.

Interstitial $\mathrm{c}-\mathrm{Kit}^{+} / \mathrm{CD} 105^{+}$cells appeared at the $17^{\text {th }}$ gestational week and persisted after birth, as shown in Table 1 and Figure 1 E-F. These double positive cells were localised only in the myocardium and were never localised inside capillaries. Many dividing cells were identified in the myocardium (Figure 1F). There were no differences between normal hearts and foetuses with heart malformations (Table 1).

From the $9^{\text {th }}$ to the $16^{\text {th }}$ gestational week, they were present only ${\mathrm{c}-\mathrm{Kit}^{+}}^{+}$(in the subepicardial space, Figure 1A, and in the myocardium, Figure 1C) or $\mathrm{CD} 105^{+}$cells (endocardium and endothelium, Figure 1B). Isl-1+ cells were present in the myocardium and in the subendocardium, with no differences between right and left ventricles. Groups of Isl-1+ $1^{+}$cells were sometimes visible, with a number ranging between $4.523 \pm 1.22 \times 10^{4}$ at the 14 th gestational week and $0.548 \pm 0.12 \times 10^{4}$ per $\mathrm{mm}^{2}$ in the post-natal age (Table 2, Figure $1 \mathrm{D}, \mathrm{G})$. The ttest for dependent variables demonstrated that the decrease in the number of Isl-1+ cells was
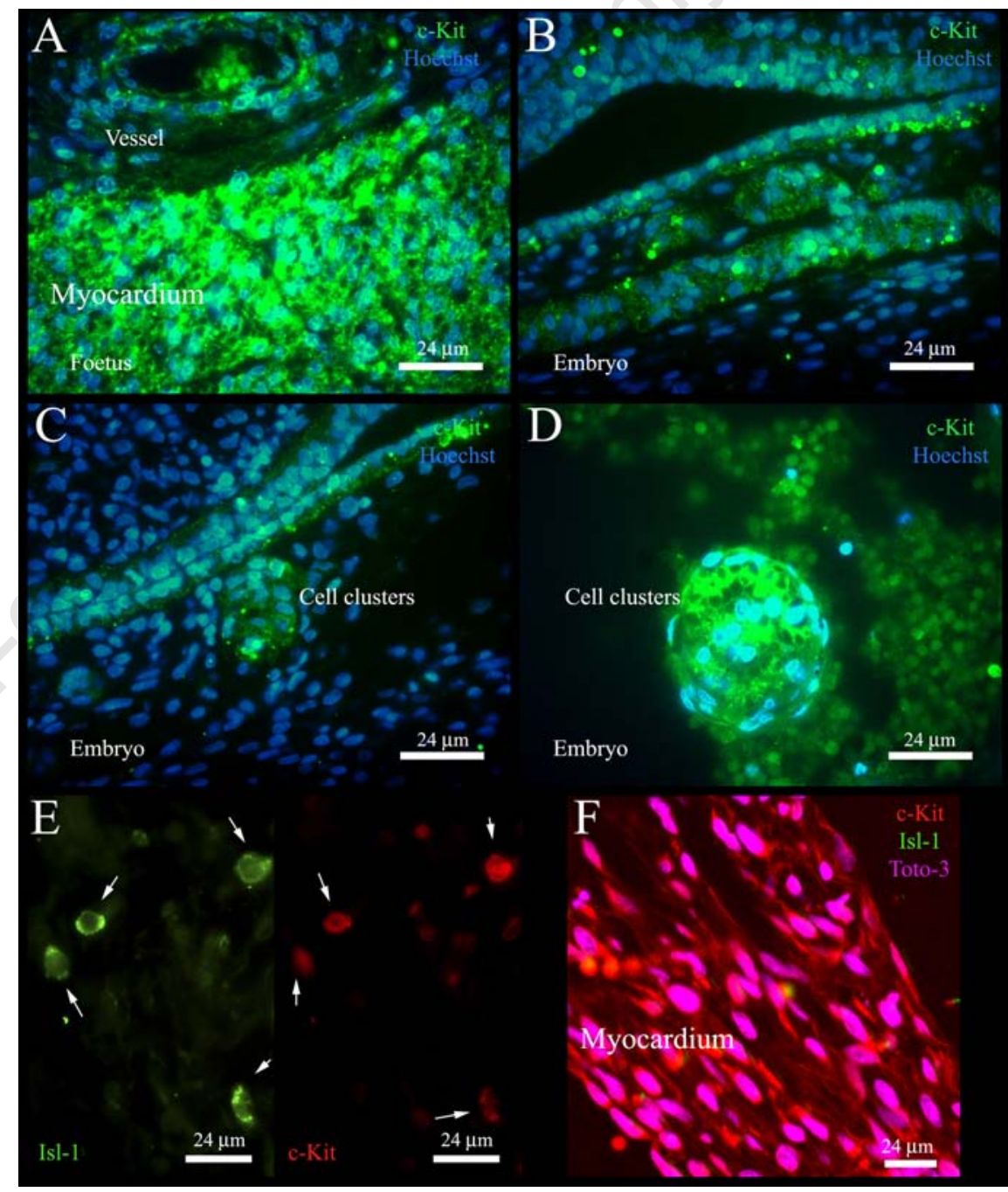

Figure 2. Expression of c-Kit and Isl-1 in embryonic and foetal hearts. A) Expression of cKit in a 16-week foetal heart. B, C) Expression of c-Kit in a 9-week human embryo. D) A cluster of c-Kit+ cells in a 15-week foetal heart. E) Co-localization of c-Kit+ and Isl-1+ cells in a 14-week foetal heart; white arrows indicate cells double positive for Isl-1 and cKit. F) Confocal microscopy analysis of the expression of c-Kit and Isl-1 in the myocardium of a 16-week foetal heart. 
significant and that this difference depended on the gestational week. The number of Isl-1+ cells was higher between the $14^{\text {th }}$ and the 16 $19^{\text {th }}$ gestational weeks and it was almost the same between the $20^{\text {th }}$ gestational week and the post-natal age. The Pearson coefficient $(\mathrm{r}=0.5 ; \mathrm{P}=0.14)$ demonstrated that there was not a linear correlation between the gestational week and the number of cells per $\mathrm{mm}^{2}$.

\section{Colocalization of c-Kit ${ }^{+} / \mid \mathrm{sl}-1^{+}$cells}

To study whether these markers were labelling the same or a different cell population, we evaluated the co-expression of c-Kit and Isl-1. We found that all the interstitial and subendocardial Isl-1+ $1^{+}$cells were positive for cKit (Figure 2E), while not all the cells positive for c-Kit were Isl-1+ (Appendix Figure 2). Cardiomyocytes were positive only for c-Kit (Figure 2F). The co-localization of the expression of c-Kit and Isl-1 on the same cell was confirmed by confocal microscopy (Appendix Figure 3).

\section{Discussion}

In this study we described the localization and the temporal distribution of $\mathrm{c}-\mathrm{Kit}^{+} / \mathrm{CD} 105^{+}$ and Isl-1+ cells from the embryonic to the postnatal heart, and we tested the hypothesis if c$\mathrm{Kit}^{+}$cells abundantly isolated from adult hearts were also present in the embryonic and foetal heart and if they represented a subset of cells different from the Isl-1 ${ }^{+}$cell population.

Cardiac precursors can be isolated from adult and post-natal hearts, ${ }^{9,32}$ and are characterized by several markers among which c-Kit both in foetal ${ }^{17}$ and adult heart, ${ }^{16}$ Isl-1 in early cardiogenesis,, 928 and CD105 in human endomyocardial biopsy specimens. ${ }^{25}$

With regard to these three CPC markers, the present study shows that Isl-1+ cells are present in the human hearts in foetuses, preterm infants and term infants, that their number decreases with the gestational week particularly after the $16-19^{\text {th }}$ gestational week, and that there is a difference in the temporal distribution of $\mathrm{c}-\mathrm{Kit}^{+}$cells. These data also show that cardiomyocytes and some interstitial cells are $\mathrm{c}-\mathrm{Kit}^{+}$from the $9^{\text {th }}$ to the $16^{\text {th }}-19^{\text {th }}$ gestational weeks, and that after this time period, only a few interstitial cells express c-Kit. Interstitial cells, which express both c-Kit and CD105 on their surfaces, are present only from the $17^{\text {th }}$ week to the 6th year of age. The presence of $c$ $\mathrm{Kit}^{+} / \mathrm{CD} 105^{+}$cells in the different stages of gestation does not demonstrate that $\mathrm{c}$-Kit ${ }^{+}$cells are resident cardiac cells. But the fact that many structures in the embryonic heart and foetal cardiomyocytes are positive to c-Kit in the early weeks of gestation provides evidence that $\mathrm{c}-\mathrm{Kit}^{+}$cells are present in the heart from the early stages of cardiogenesis, and their number decreases during gestation until the postnatal age.

We also demonstrated that the interstitial and subendocardial Isl-1+ ${ }^{+}$cells are positive also to c-Kit. The co-localization of the two CPC markers let us suppose that Isl- $1^{+}$cells are a subset of the $\mathrm{c}-\mathrm{Kit}^{+} \mathrm{CPCs}$ population usually isolated and identified in the adult heart.

The hypothesis that $\mathrm{c}-\mathrm{Kit}^{+}$human CPCs are more abundant in the early stages of gestation and that their number decreases over time is supported by a recent paper, where the authors isolated and grown human CPCs from neonate and infant specimens. ${ }^{33}$ The $\mathrm{c}-\mathrm{Kit}^{+}$cells that the authors isolated and expanded were also positive to Isl-1 in culture inside cardiospheres, supporting our hypothesis that the postnatal Isl- $1^{+}$cells may be a subpopulation of c-Kit ${ }^{+}$human CPCs, which originate from the embryonic pre-cardiac mesoderm and probably persist in the adulthood.

In conclusion, we have demonstrated that foetal cardiomyocytes are positive to c-Kit, and that foetal Isl-1+ ${ }^{+}$cells are a subset of foetal c$\mathrm{Kit}^{+} \mathrm{CPCs}$. A better understanding of the localisation and migration of CPCs during cardiogenesis may be achieved using mouse or zebrafish transgenic models.

\section{References}

1. Snarr BS, Kern CB, Wessels A. Origin and fate of cardiac mesenchyme. Dev Dyn 2008;237:2804-19.

2. de la Cruz MV, Sanchez Gomez C, Arteaga MM, Arguello C. Experimental study of the development of the truncus and the conus in the chick embryo. J Anat 1977;123:66186.

3. Di Felice V, Zummo G. Tetralogy of fallot as a model to study cardiac progenitor cell migration and differentiation during heart development. Trends Cardiovasc Med 2009;19:130-5.

4. Waldo KL, Kumiski DH, Wallis KT, Stadt HA, Hutson MR, Platt DH, et al. Conotruncal myocardium arises from a secondary heart field. Development 2001; 128:3179-88.

5. Kelly RG, Brown NA, Buckingham ME. The arterial pole of the mouse heart forms from Fgf10-expressing cells in pharyngeal mesoderm. Dev Cell 2001;1:435-40.

6. Kelly RG, Buckingham ME. The anterior heart-forming field: voyage to the arterial pole of the heart. Trends Genet 2002;18:210-6.

7. Laflamme MA, Murry CE. Heart regenera- tion. Nature 2011;473:326-35.

8. Cai CL, Liang X, Shi Y, Chu PH, Pfaff SL, Chen J, et al. Isll identifies a cardiac progenitor population that proliferates prior to differentiation and contributes a majority of cells to the heart. Dev Cell 2003;5: 877-89.

9. Laugwitz KL, Moretti A, Lam J, Gruber P, Chen Y, Woodard S, et al. Postnatal isl1+ cardioblasts enter fully differentiated cardiomyocyte lineages. Nature 2005;433:64753.

10. Rochais F, Mesbah K, Kelly RG. Signaling pathways controlling second heart field development. Circ Res 2009;104:933-42.

11. Genead R, Danielsson C, Wardell E, Kjaeldgaard A, Westgren M, Sundstrom E, et al. Early first trimester human embryonic cardiac Islet-1 progenitor cells and cardiomyocytes: Immunohistochemical and electrophysiological characterization. Stem Cell Res 2010;4:69-76.

12. Bu L, Jiang $X$, Martin-Puig S, Caron L, Zhu S, Shao Y, et al. Human ISL1 heart progenitors generate diverse multipotent cardiovascular cell lineages. Nature 2009;460: 113-7.

13. Amir G, Ma X, Reddy VM, Hanley FL, Reinhartz 0, Ramamoorthy C, et al. Dynamics of human myocardial progenitor cell populations in the neonatal period. Ann Thorac Surg 2008;86:1311-9.

14. Di Felice V, Ardizzone NM, De Luca A, Marciano V, Gammazza AM, Macaluso F, et al. OPLA scaffold, collagen I, and horse serum induce an higher degree of myogenic differentiation of adult rat cardiac stem cells. J Cell Physiol 2009;221:729-39.

15. Forte G, Carotenuto F, Pagliari F, Pagliari S, Cossa P, Fiaccavento R, et al. Criticality of the biological and physical stimuli array inducing resident cardiac stem cell determination. Stem Cells 2008;26:2093-103.

16. Di Felice V, De Luca A, Colorito ML, Montalbano A, Ardizzone NM, Macaluso F, et al. Cardiac stem cell research: an elephant in the room? Anat Rec 2009;292:44954.

17. Limana F, Zacheo A, Mocini D, Mangoni A, Borsellino G, Diamantini A, et al. Identification of myocardial and vascular precursor cells in human and mouse epicardium. Circ Res 2007;101:1255-65.

18. Amir G, Miller L, Shachar M, Feinberg MS, Holbova R, Cohen S, et al. Evaluation of a peritoneal-generated cardiac patch in a rat model of heterotopic heart transplantation. Cell Transplant 2009;18:275-82.

19. Linnekin D. Early signaling pathways activated by c-Kit in hematopoietic cells. Int $\mathrm{J}$ Biochem Cell Biol 1999;31:1053-74.

20. Riccio M, Resca E, Maraldi T, Pisciotta A, Ferrari A, Bruzzesi G, et al. Human dental 
pulp stem cells produce mineralized matrix in $2 \mathrm{D}$ and $3 \mathrm{D}$ cultures. Eur $\mathrm{J}$ Histochem 2010;54:e46.

21. Wu Y, Li J, Saleem S, Yee SP, Hardikar AA, Wang R. c-Kit and stem cell factor regulate PANC-1 cell differentiation into insulinand glucagon-producing cells. Lab Invest. 2010;90:1373-84.

22. Calo PG, Esu F, Tatti A, Pilloni L, Madas F, Pisano G, et al. Isolated inguinal endometriosis. Case report with ultrasonographic preoperative diagnosis. G Chir 2011;32:263-5.

23. Anversa P, Kajstura J, Leri A, Bolli R. Life and death of cardiac stem cells: a paradigm shift in cardiac biology. Circulation. 2006;113:1451-63.

24. Di Nardo P, Forte G, Ahluwalia A, Minieri M. Cardiac progenitor cells: potency and control. J Cell Physiol 2010;224:590-600.

25. Smith RR, Barile L, Cho HC, Leppo MK, Hare JM, Messina E, et al. Regenerative potential of cardiosphere-derived cells expanded from percutaneous endomyocardial biopsy specimens. Circulation 2007;115:896-908.

26. Fonsatti E, Maio M. Highlights on endoglin (CD105): from basic findings towards clinical applications in human cancer. J Transl Med. 2004;2:18.

27. Pierelli L, Bonanno G, Rutella S, Marone M, Scambia G, Leone G. CD105 (endoglin) expression on hematopoietic stem/progenitor cells. Leuk Lymphoma 2001;42:1195206.

28. Moretti A, Caron L, Nakano A, Lam JT, Bernshausen A, Chen Y, et al. Multipotent embryonic isl1+ progenitor cells lead to cardiac, smooth muscle, and endothelial cell diversification. Cell 2006;127:1151-65.

29. Laugwitz KL, Moretti A, Caron L, Nakano A, Chien KR. Isletl cardiovascular progenitors: a single source for heart lineages? Development 2008;135:193-205.
30. Zhou B, Ma Q, Rajagopal S, Wu SM, Domian I, Rivera-Feliciano J, et al. Epicardial progenitors contribute to the cardiomyocyte lineage in the developing heart. Nature 2008 3;454:109-13.

31. Baschong W, Suetterlin R, Laeng RH. Control of autofluorescence of archival formaldehyde-fixed, paraffin-embedded tissue in confocal laser scanning microscopy (CLSM). J Histochem Cytochem 2001;49:1565-72.

32. Anversa P, Leri A, Rota M, Hosoda T, Bearzi C, Urbanek K, et al. Concise review: stem cells, myocardial regeneration, and methodological artifacts. Stem Cells 2007; 25:589-601.

33. Mishra R, Vijayan K, Colletti EJ, Harrington DA, Matthiesen TS, Simpson D, et al. Characterization and functionality of cardiac progenitor cells in congenital heart patients. Circulation 2011;123:36473. 